\title{
Economics of Austerity and Its Social Cost: A Critical Assessment of IMF Policies in Pakistan from 1988-2002
}

\author{
Dr. Manzoor Ali Isran ${ }^{1}$ \\ Dr. Samina Isran ${ }^{2}$
}

\begin{abstract}
The paper attempts to analyze the impact of the economics of austerity in the form of structural adjustment programmes singed by government with IMF during 1988-2002. To assess the impact of SAP on the vital macroeconomic indicators, the paper has adopted qualitative and quantitative research methodology while collecting data from different sources, including State Bank of Pakistan. This paper assesses the social impact of IMF conditionalities on health, education in addition to social consequences of privatization and withdrawal of subsidy. It has been deduced from the data that there has been major reduction on the expenditure on health and education as a result of cuts on healthcare and education as certain portions of the budget such as the defense, debt servicing and government salaries are fixed and the cut in the budget translates into cut in social sector expenditure which eventually impacted on health, education and other relevant sectors of the economy. This had have negative implications for the quality of services provided in education, curative health care and provision of medicines, largely due to protecting recurring budgets in the face of cutbacks. Education is an important sector of economy since it is a key component of the strategy for sustainable development and the best way to build a modern and coherent community. Cuts in educational expenditures had worst consequences for both the quality and quantity of education provided to students. Governments in the past had reacted by reducing education budget which resulted in decline in real education expenditure per student. Hence cut in education expenditure affects both the quality and quantity of education provided to the population by any government and can be linked directly to structural adjustment programs. The other area that produced negative social consequences during adjustment period is the privatization. Though IMF saw privatization as panacea to the economic woes of Pakistan, it failed to produce the desired results. From 1991 to 2006 the GOP privatized more than 160 public units at gross price of Rs. 395 billion and about 0.6 million workers were rendered jobless as a result of neo-liberal IMF (SAP) policies.
\end{abstract}

Keywords: IMF, structural adjustment programmes, Pakistan, health, education, privatization, social consequences

\section{Introduction}

Pakistan economy was on rollercoaster ride during 1988-2002 due to misconceived monetary and fiscal policy, coupled with political instability, bad governance and rising corruption. Most of the leading economist called this period 'Lost Decade of Development. Financial indiscipline, soaring fiscal deficit, low level of revenue generation and growing misutilization of resources hit the economy hard. The upshot of all this was that the economy was thrown into cesspool of insolvency and bankruptcy. The foreign exchange reserve plummeted drastically, GDP reduced, growth nosedived, inflation and unemployment hiked and exports slumped. The country needed financial cushioning to prop up the economy. So, in an effort

\footnotetext{
${ }^{1}$ Dr. Manzoor Ali Isran is Associate Professor, Department of Social Sciences, at SZABIST, Karachi, isran@szabist.edu.pk

2 Dr. Samina Isran is Assistant Professor, Department of Economics, Shah Abdul Latif University, Khairpur, saminaisran@htomail.com

\begin{tabular}{llll|l}
\hline JISR-MSSE & Volume 12 & Number 1 & January-June 2014 & 93
\end{tabular}
}


to stabilize macroeconomic conditions and address the issue of balance of payment, Pakistan joined IMF programmes and accepted structural adjustment programme in 1988, with set of conditionalities such as liberalization of the market, privatization, deregulation, downsizing, withdrawal of subsidy, improving tax structure, removing barriers from trade and imports and devaluing currency.

The following were the key conditions of 1988 and other structural adjustment programmes signed by different government between 1988 and 2002.

- $\quad$ Reduce the overall budgetary deficit from 6.5 per cent of the GDP in 1988-89 and to 5.5 per cent in 1989-90 to 4.8 per cent in 1990-01;

- Contain the rate of inflation to 10 per cent in 1988-89 and reduce it gradually to 7 per cent by $1989-90$ and to 6.5 by $1990-91$;

- Reduce the external current account deficit to 3.4 per cent of GDP in 1988-89, and further to 2.8 per cent by $1989-90$ and 2.6 by $1990-91$;

- Reduce the civilian external debt service ratio from $27-28$ per cent in $1986-88$, to the sustainable level of less than 22 per cent in 1990-91;

- Increase gross official foreign exchange reserves from the equivalent of above three week of merchandise imports at end-1987-89 to a level of about seven weeks of imports by 1990-91; and

- Contain the growth of domestic credit and money supply in line with the growth of nominal GDP at the target rate of inflation, with sufficient allowance for the desired increase in net foreign assets.

The set of conditionalities attached with 1988 adjustment package were incorporated in the budget of 1989-90. Sales tax was imposed on 44 items. Excise duties were imposed on some other services such as travel, advertisement and hotels in addition to telephone, post and telegraph. Tariffs were imposed on key urban services like water and sewerage. In Agriculture, the government reduced the support price for essential crops like wheat, rice, cotton, sugarcane and oil seeds to ensure that they were in line with the levels and trends in international market prices.

IMF Standby Facility was signed in 1993 for SDR 26 million for three years with conditionalities which have become part of the IMF programme. The Budget of 1995-96 reflected a controversy between the Government of Pakistan and IMF. According to the agreement, budgetary deficit had to be reduced to 4 per cent of GDP while Pakistan had reduced it to 5 per cent. Another controversy was regarding the reduction of tariff rates. According to the agreement, it was to be reduced to 45 percent while the government had reduced it to 65 per cent only. The government's point view was that they had not gone against the objectives of the programme but they had only slowed it down because heavy taxes would have to be imposed to reduce the deficit to 4 per cent. Similarly, reduction in tariff rates would have affected revenue. Moreover, industries were to be given to adjust to new competition from aboard. The IMF did not agree and suspended Extended Structural Adjustment Facility (ESAF) and Extended Fund Facility (EFF) programmes. In fact they went to the extent of eventually cancelling both lending.

Hardly four months had passed that Pakistan had to change its approach as the fall in exports and decline in foreign exchange resources from 2.7 billion US dollars in June 1995 to 1.2 
billion dollars in October 1995 led the government to devalue the rupee by 7 per cent and impose the regulatory duty of 5 to 10 per cent on imports. Further a rise of 7 per cent was also imposed on petroleum prices. After taking these measures, Pakistan approached the IMF for Standby loan of 600 million dollar at a market rate of 5 per cent to be repayable in 15 months. It indicated how strong the hold of IMF on the Pakistan's economy was.

The most severe crisis occurred in the aftermath of nuclear explosion conducted by Pakistan on May 28 1998. The seven month period - a period up to the approval of IMF programme in January 1999 - was a period of real trial and the country came close to the brink of default.

If it is evaluated minutely, the main focus of the IMF programmes since 1988 remained fiscal deficit. While concluding all long and short term agreements, Pakistan was told by the IMF to lower its fiscal deficit to 4 per cent of GDP. The ways of achieving this had involved high taxation and a decrease in public expenditure. In three years alone (1994-97), additional taxes of Rs 140 billion were imposed on the people without a significant widening of the tax base. Those who were already paying taxes had had their tax burden increased through higher sales taxes and other indirect taxes, while the expansion in the number of new direct taxpayers had been negligible. Despite this surge in mainly indirect taxation, the government was unable to meet the 4 per cent target, and had to resort to a reduction in public expenditure. Even today, Pakistan government led by business tycoon Mian Nawaz Sharif is doing the same thing; increasing the indirect taxes, which has lethally contributed to inflation against which people are protesting but to no avail.

As a matter of fact, Pakistan signed different Structural Adjustment agreements with IMF from 1988-2002, with the sanguine hope that these agreements will enable governments to stabilize economy and political system and put society back on the rails of socio-economic development. But this has not happened and on the contrary during 1988-2002 country plunged into socio-economic and political crises. It witnessed high inflation rate, soaring unemployment, and increasing fiscal deficit. It drew serious concern from some of the economists and described the decade of nineties as 'Lost Decade of Development' (Ishrat, 2004, Zaidi, 2006,).

Section II provides the literature review in which the views of the opponents and proponents are presented. Section III presents the discussion and results of the socio-economic impact of IMF programmes on health, education and also the assessment of the privatization and its social impact is evaluated. The section IV presents the criticism of the IMF programmes by the civil society and Section V concludes why IMF programmes have failed in Pakistan to produce the desired results.

\section{Literature Review}

IMF programmes are viewed as mix bag of success and failure. Successes are dependent on the domestic conditions (Vreeland, 2007). If domestic conditions are stable - country has effective system of governance, stable political system, functional institutions and strong system of accountability then IMF programmes are likely to be successful. Turkey under is glaring example of this. But if these conditons are not prevailing in any country then country will face more hardships and economic crisis due to IMF conditionality of austerity. Pakistan is good example of the failure of IMF-led economic reforms where there are no effective, inclusive economic institutions and no good governance. 
First let us review some of the studies which are very critical of IMF programmes: Rowden (2009) in his book "The deadly ideas of neoliberalism: How the IMF has undermined public health and the fight against AIDS", argues that "IMF fiscal and monetary policies are tantamount to 'health repression' and are undermining global health goals, and that public financing to support health systems needs to be 'liberated' from such constraints through the freedom for developing countries to use more expansionary fiscal and monetary policy options."

The study blames IMF for neglecting development goals, sustained growth which could improve the well-being of the poor and create fiscal space for increasing priority spending, including health at the altar of financial stability through monetary and fiscal policy. Rowden criticizes IMF for continually failing to grasp health campaigners' main critique: that the IMF's "underlying ideological disposition ... prioritizes short-term financial sector variables in macroeconomic policy to the subordination or neglect of real sector variables, such as long-term developmental goals, industrialization, higher employment or increased public investment."

The UN is also critical of the IMF programmes in the Third world and describes them bad for the poor because they cause inflation. In its World Social Situation 2010 Report, which was released in January, the UN Department for Economic and Social Affairs argues "the one-sided fight against inflation ignores the impact of employment creation, the net debtor position of most of the poor, and the negative consequences of tight monetary policy and reduced social spending during recessions. "Focusing on inflation and fiscal deficits alone reflects too narrow a view of stabilization."

A study undertaken by the University of Cambridge establishes a relationship between IMF conditions and sharp rise in TB, a disease related to severe poverty conditions, worst health infrastructure commonly found in Africa or other poorer regions. It shows that whenever IMF makes adjustment loans, it demands structural adjustment programs. In every case the prescription is same; the targeted Governments have to cut their social sector development expenditure including public health to control inflation. A study by David Stuckler, quoted by Engdahl (2009) at the University of Cambridge analyses more than 21 countries of Central and Eastern Europe that were involved with borrowing from IMF for different amounts after 1989. He found out that IMF countries had significantly more TB cases, and more deaths than countries without IMF loans. TB death rates in these countries are average six cases per 100,000 of the total population. This increased to 12 per 100,000 by 2003 in the above mentioned IMF countries, the Cambridge university scientists found that because of IMF loans, government spends less on health, fewer doctors per person, and a cut of nearly half of the people with TB that received directly observed therapy (DOTS) which requires investment in public health staff for eradicating DOTS (Engdahl, 2009).

Gera (2007) in a detailed work entitled "SAP in Pakistan: A boon or bane?" analyzes the impact of structural adjustment on various socio-economic conditions. She argues that macroeconomic stabilization is not beneficial for everyone in the economy and there is a need to see the impact on poverty and inequality. She raises an important question: Is economic growth adequate for poverty removal? She admits that it is difficult to establish causality between structural adjustment and social welfare. 
Gera (2007) has analyzed the situation of food security in Pakistan during the structural adjustment era. She quotes Josue de Castro who emphasized on the importance of food security: "because of its explosive social implications the subject (of hunger) until very recently has been one of the taboos of our civilization. She argues that food production has more than doubled since 1960s and South Asian countries were self-sufficient in food in 1970s and 1980s. The report highlights the importance of public action in order to improve food security. The report argues that food insecurity and poverty are two twin problems that have emerged since early 1990s. The demand for food has always exceeded the supply. From late 1980 s to late 1990 s food security for the poor suffered due to rising unemployment and falling wages. Although the writer has provided sound arguments in favor of food security but the study lacks to link rise in food insecurity to structural adjustment programs.

Another prominent economist Kemal (2001) analyzes the poverty trends during adjustment era using three methods viz head count, income gap and inequality amongst poor. According to Kemal (2001), poverty in Pakistan increased sharply from $17.8 \%$ persons falling below poverty line to $22.4 \%$ from $1987-88$ to $1992-3$. The incidence of poverty was more widespread in rural areas (34.8\%) as compared to urban areas (25.5\%). Unemployment also increased from $4.7 \%$ in $1992-93$ to $6.4 \%$ in $1998-99$. The data was collected from Household Income and Expenditure Surveys (HIES) and Pakistan Integrated Household Surveys (PIHS) conducted by the Federal Bureau of Statistics. He concludes that under the stabilization programs, the public investment tends to fall with a very strong multiple impacts on employment and poverty as public investment focuses on construction of projects that are labor-intensive (ibid).

Khan (1990) analyzes the poverty during adjustment era and argues that cutting expenditure translates into cut in subsidies and expenditure on social sector. Using the Household monthly income data, he shows that real income decreased from 1987-88 to 1990-91 and concludes that structural adjustment policies are detrimental for the socio-economic well-being of the poor.

Hameed and Nazeer (2013) in their work, 'Economic Globalization and its Impact on Poverty and Inequality' analyzed the impact of trade liberalization on poverty and inequality in Pakistan by employing Granger causality testing (VECM and TYDL approach). They analyzed the data on poverty, income inequality, gross domestic product (GDP), population, unemployed labor force and employed labor force collected from economic survey of Pakistan over the period 1970-2004. The report points out that while trade liberalization allowed many LDCs preferential market access to from both developed and developing countries, but this does not necessarily help in poverty reduction. The findings indicate that globalization reduces poverty in the long-run and generates employment opportunities, but at the same it widens inequalities between haves and have-nots. Although globalization is considered healthy for economies, its adverse effects may result in increasing poverty and income disparity. They concluded that if Pakistan wants to benefit from economic globalization, then it must adopt pro poor growth policies by investing in human development and providing social safety nets for the poor.

Likewise, Khan (2002) has analyzed the impact of structural adjustment on health expenditure in Pakistan. They focus more on the health indicators. Using results based methodology; the report focuses on access to health facilities such as doctors, nurses and hospital beds. The 
study concludes that while health sector has progressed, much more is needed to be done. As compared to South Asian countries, Pakistan lags behind in all child survival statistics, in particular.

\subsection{Defense of IMF Programs}

IMF has responded sharply to criticism of its programmes. However, the main defense has come from Kenneth Rogoff, a Harvard professor and former Chief Economist of IMF. Rogoff in his paper "IMF Strikes back (2003) terms the criticism "polemic and deeply misguided" (p. 1). He brushes aside all the criticism leveled against IMF for imposing austerity on barrowing country, pushing for high interest rates, opposing tax cuts and reducing public expenditure (Rogoff, 2003). Opponents of the programmes argue that such harsh conditionality harm poor and produce economic crisis than alleviating and stabilizing economies of the borrowing countries (Vreeland, 2003) But Rogoff argues that such conditionalities are essential keeping in view the level of bad economic management and the very purpose of such conditionalities is to put economies back on the road of stability.

In another study, IMF economist Beke (2002), an IMF economist, also supports IMF programmes, which according to him, are designed to promote good governance and combat corruption through policy advice, programme conditionality and technical assistance. He argues that IMF programmes bring more effectiveness, degree of transparency, and accountability of policy makers. The purpose is to meet the accepted standards of good policies and prevent corruption (Beke, 2002).

Apart from the merits of the arguments of the proponents of IMF programmes, empirical data hardly shows that IMF programmes of conditionality have been successful in preventing corruption and improving governance. For example education is considered to be one of the strong factors of macroeconomic stability in the long run but IMF-imposed conditionality of austerity has resulted in the reduction of education and health budgets and resultantly the closure of schools and hospitals (discussed in the next section). With regard to corruption, according to Transparency International Corruption Perceptions Index 2013, Pakistan ranks 127 in overall ranking, stands behind Togo, Gambia and East Timor (Transparency International, 20013)

\section{Discussion and Results}

\subsection{Impact of SAP on Overall SocialSector Expenditure}

There are different factors that may contribute to declining government expenditure on Social sector, but clearly the contribution of SAP policies to the declining social sector expenditure in Pakistan is substantial. Here, certain portions of the budget such as the defense, debt servicing and government salaries are fixed and the cut in the budget translates into cut in social sector expenditure which eventually negatively impact, on health, education and other relevant sectors of the economy. 


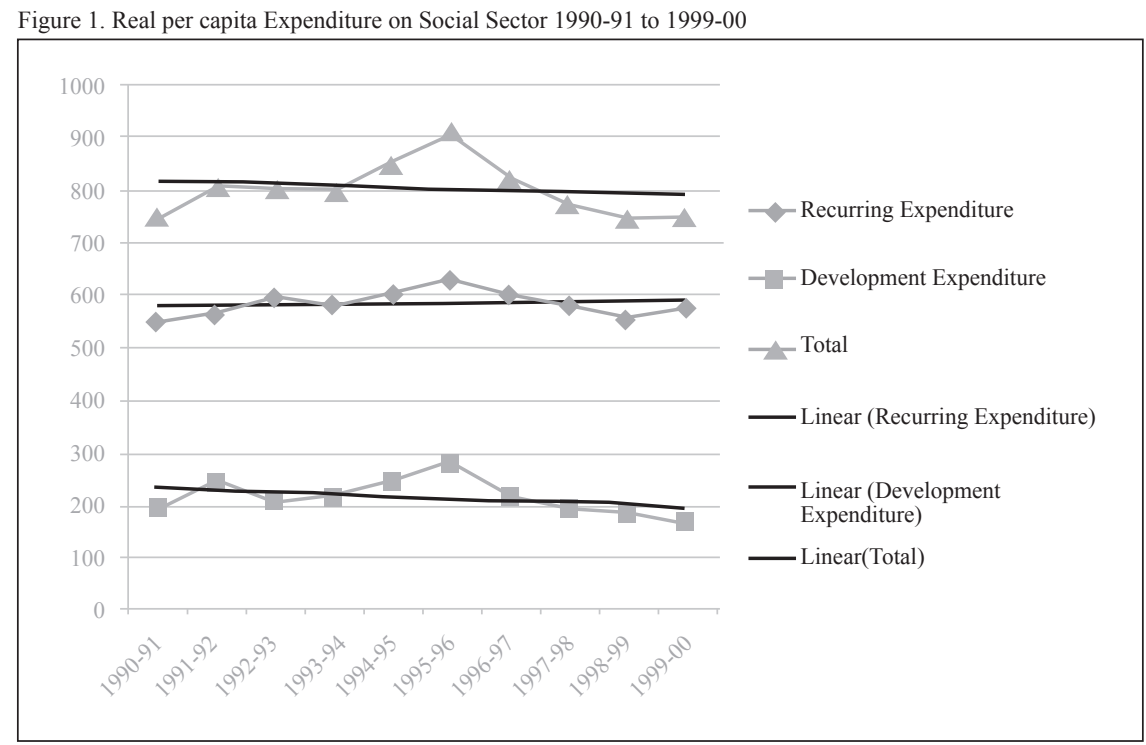

Source: Social Policy and Development Centre. Social Development in Pakistan, 2000, Karachi, p. 152.

The above graph shows the trend of real capita expenditure on social sectors in Pakistan from 1990-1 to 1999-00. It shows a declining trend in both recurring and development expenditure but the decline in development expenditure is sharper, it indicates the negative impact on health, education and other sectors. The declining trend continues except in the year 19951996, when the per capita expenditure rose to a peak level, largely due to increased government spending under the Social Action Program (SAP). But the rest of the period shows decreasing expenditure on social sectors of the economy. It also means that it had a negative impact on the development of health and educational facilities during the structural adjustment era. According to Social policy and Development Review (2000), this has had negative implications for the quality of services provided in education, curative health care and provision of medicines, largely due to protecting recurring budgets in the face of cutbacks. The decline in development expenditure is steeper than recurring expenditures. There has been a cutback of almost 40 percent, showing that the expansion rate of facilities has declined sharply.

\subsubsection{Impact of Structural Adjustment on Health in Pakistan}

Health sector is an important sector of any economy and it is the responsibility of government to provide health service to the people living in the country. Government expenditures in health sector greatly affect the overall health situation in any developing country. As discussed earlier in this paper, IMF Structural Adjustment policies affect the Health Sector of Developing economies due to cuts in government spending on the health sector. The impact of structural adjustment policies on health sector in Pakistan both in terms of expenditure on health and its effects on health indicators has been analyzed. 


\subsubsection{Impact on Health in terms of Expenditure}

The impact of structural adjustment policies on government allocation of funds in the health sector has been analyzed by comparing the expenditure on health as \% of GDP deriving both IMF and Non-IMF period.

The Figure 2 below shows government expenditure on health as \% of GDP from year 1980 to 1988. An overall increasing trend which indicates increasing government expenditure on health during this period can clearly be seen. The peak point in the graph is in the year 1987 when the expenditure increased to approximately $1.2 \%$ of GDP. When this graph is compared with graph 2, showing expenditure from 1988 onwards, the declining trend in the expenditure on health as \% of GDP can clearly be seen. The two lowest points on the graph are during the year 1994 and 2000, when government expenditure decreased to $0.72 \%$ of GDP.

Figure 2. Expenditure on health as \% of GDP from 1980 to 1988

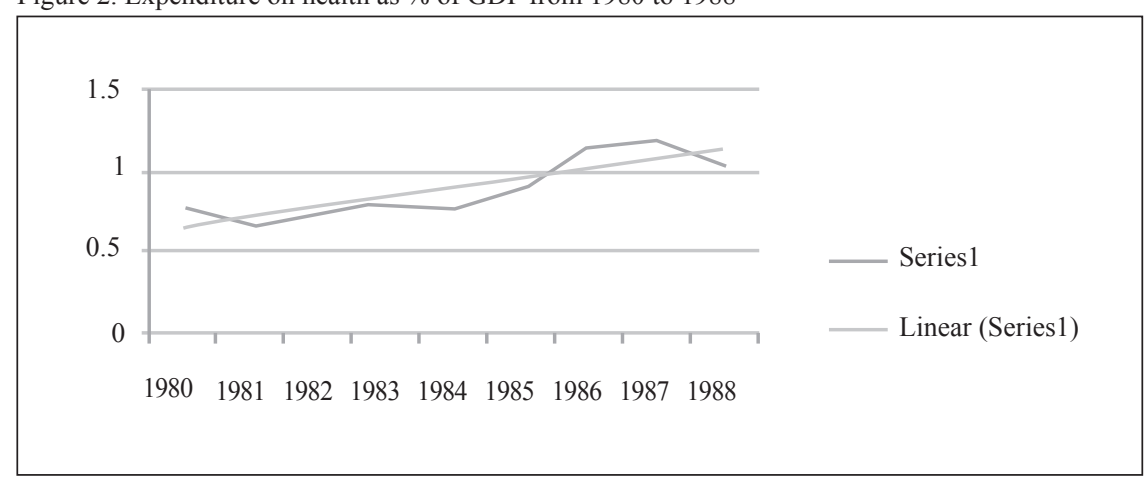

Source: State Bank of Pakistan. Handbook of Statistics on Pakistan Economy, 2005, p. 526.

Figure 3. Expenditure on Health as \% of GDP from 1988-2000

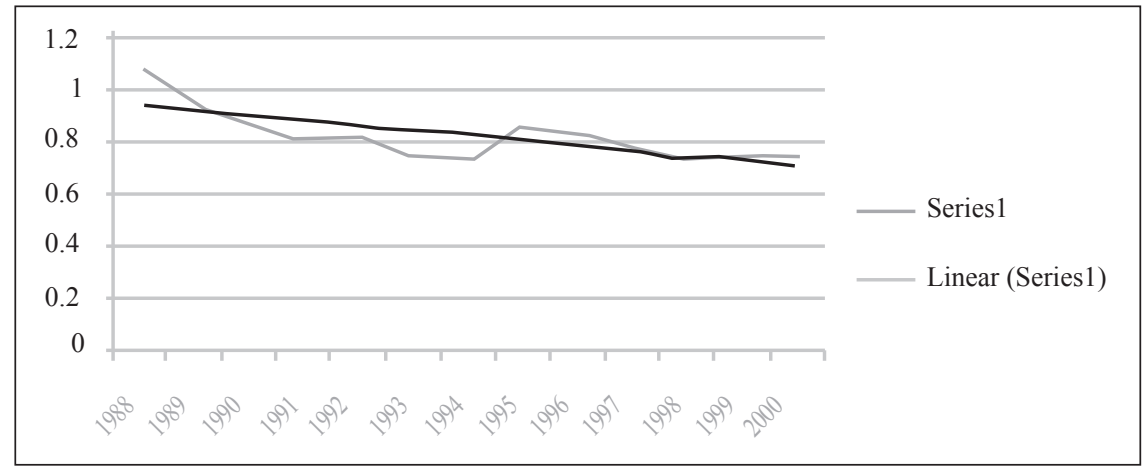

Source: State Bank of Pakistan, Karachi. Handbook of Statistics on Pakistan Economy, 2005, p. 526. 
Comparing the two graphs, it can be seen that the Health expenditure went down during the adjustment era and the adjustment policies had a negative impact on the health sector of the economy. The results are also consistent with UNICEF report which concluded that structural adjustment had negative effect on health in developing economies.

\subsubsection{Analysis of Per Capita Expenditure on Health}

The next graph 4 on per capita expenditure shows overall increasing trend which implies that the health resources per capita had been increasing since 1980. There was sharp increase in per capita expenditure from approximately Rs.100 per capita in 1994 to Rs. 144 in 1996. This was mainly due to the Social Action Program initiated by Prime Minister Benazir Bhutto. The per capita expenditure on health increased sharply in 1994 and continued till 1996. This trend contradicts the UNICEF study which cited example of Ghana where $80 \%$ cut in per capita health expenditure was observed due to adjustment policies.

The increasing trend of per capita expenditure may seem contradictory because of the declining government expenditure on health but it may be due to overall increase in the pool of resources available to government over the period of time.

Figure 4. Per capita health expenditure

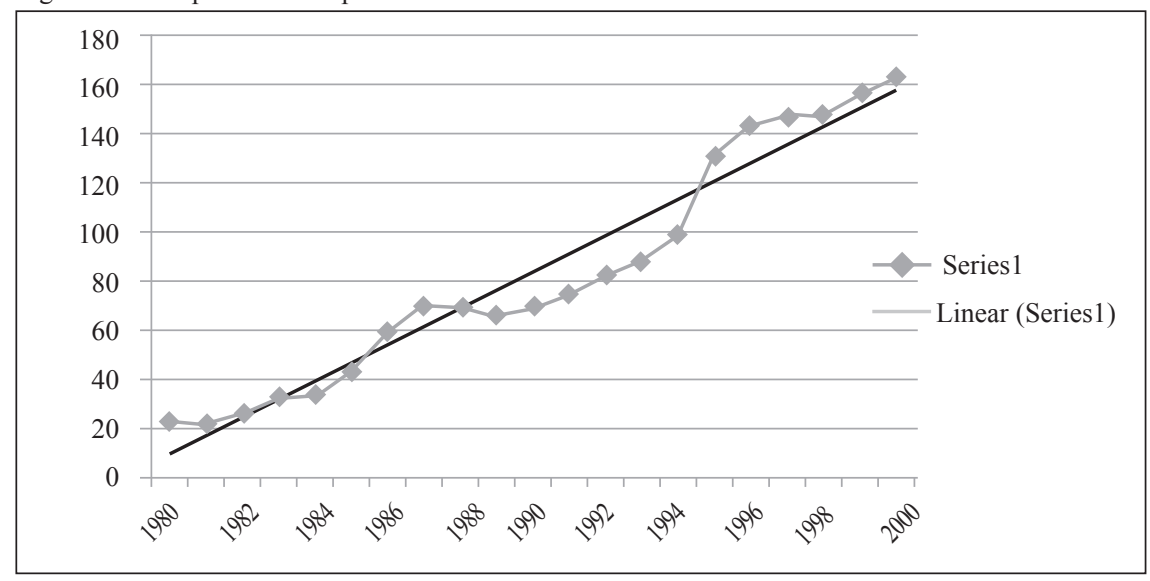

Source: State Bank of Pakistan. Handbook of Statistics on Pakistan Economy, 2005, Karachi, p. 526.

\subsubsection{Impact on Health Facilities Available to the Public}

Through the above graphs, an attempt was made to analyze the impact on expenditure, and the impact of the decline in public health expenditure on different health indicators and there indicators were used because numerous studies reviewed in previous chapters focused on the impact of cut in health expenditures and on health indicators. For instance, David Stucker's research (2009) showed that the countries with IMF loans had worse health indicators as compared to countries without IMF loans. The study pointed out that due to structural adjustment, investment in health declined. As such lesser numbers of doctors were available per person and hence more cases of tuberculosis. 
Figure 5. Population per Doctor

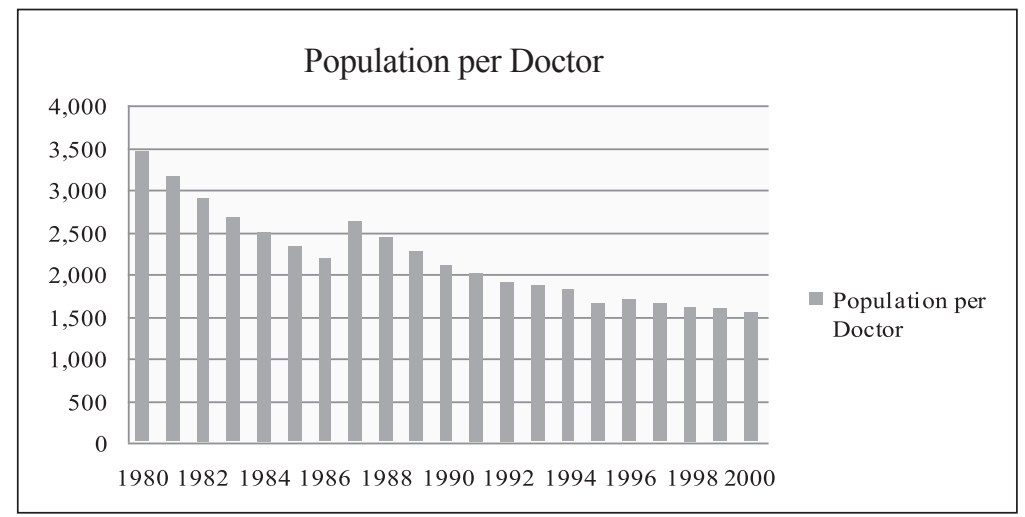

Source: State Bank of Pakistan. Handbook of Statistics on Pakistan Economy, 2005, Karachi, p. 524

The population per doctor statistics clearly documents about the number of people who are dealt with by one doctor. The graph here shows overall decline in the population per doctor which indicates improvement in availability of doctors, but it does not tell about the quality of services provided to the patients. The graph shows decline in population per doctor from 1980-87 and then there is marked increase in the year 1988.

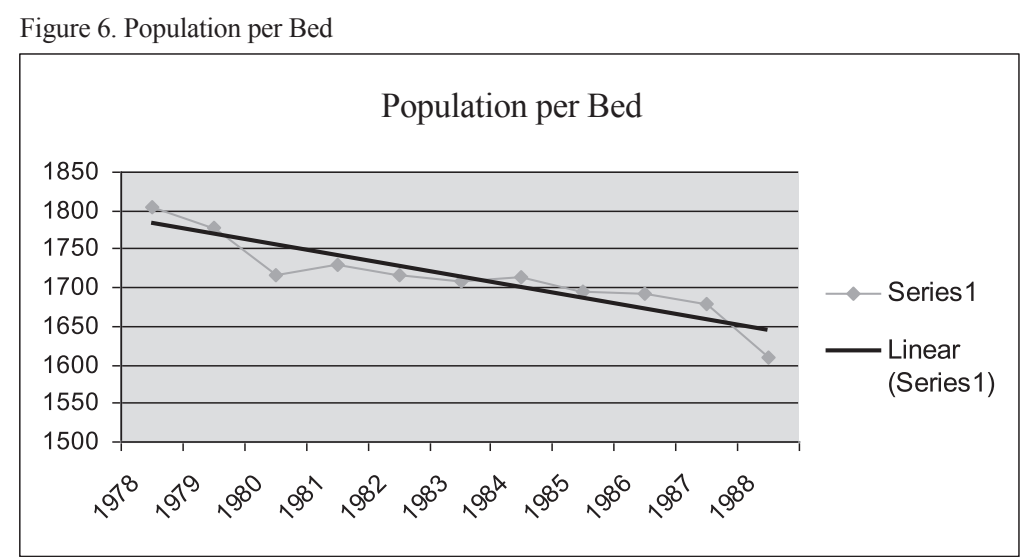

Source: State Bank of Pakistan. Handbook of Statistics on Pakistan Economy, 2005, Karachi, p. 522.

Figure 6 on Population per bed statistics indicates the impact, if any, of structural adjustment policies on health facilities available to the population of Pakistan. Both the periods i.e. NonIMF and IMF periods show a declining trend in Population per bed, hence implying that the overall health facilities improved in both IMF and non-IMF era with similar trends. 
Figure 7. Population per bed

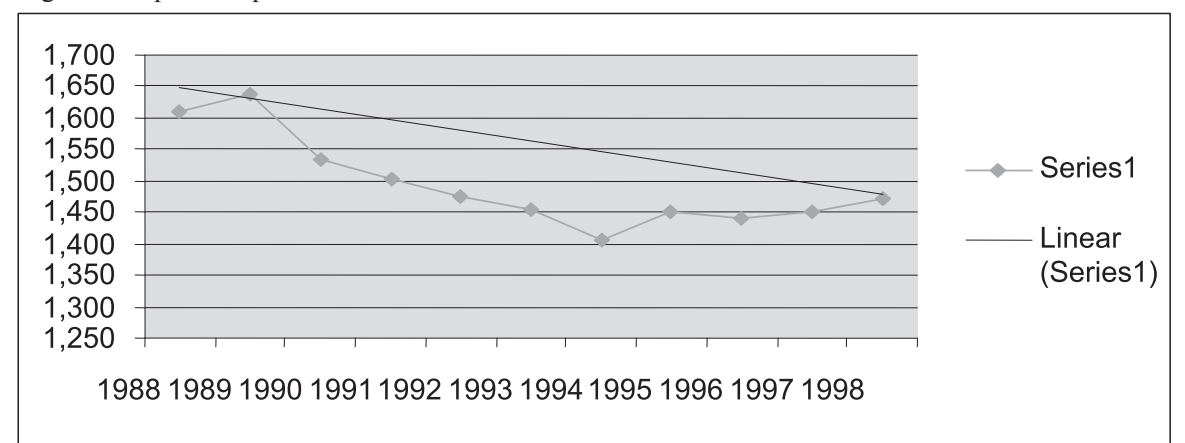

Source: State Bank of Pakistan. Handbook of Statistics on Pakistan Economy, 2005, Karachi, p. 526.

The results contradict with those suggested by David Stuckler, which concludes that health facilities did not grow well during adjustment era. There may be other factors that contributed to increase in health facilities, because the trend is similar in both areas. Comparing the two periods from 1978-88 and 1988-98, it is clear that the trend is similar without any significant changes.

Hence the overall analysis shows that the structural adjustment policies had negative impact on health sector expenditure in Pakistan, whereas the indicators showed a similar trend with no significant increase during the last two decades. Health expenditure as \% of GDP declined during adjustment era but per capita expenditure on health increased sharply.

\subsection{Impact of Structural Adjustment on Education Sector}

Education is an important sector of economy since it is a key component of the strategy for sustainable development and the best way to build a modern and coherent community. Education is a long-term investment and it helps countries to progress well. Unfortunately, education is not given its due importance in developing countries like Pakistan.

As earlier in the analysis, structural adjustment policies have led to cut in overall social sector expenditure, which in turn, had a negative impact on the social welfare of the poor masses in Pakistan. Following section will analyze the impact of structural adjustment on the education sector in Pakistan.

Figure 8 . Education expenditure as $\%$ of GDP

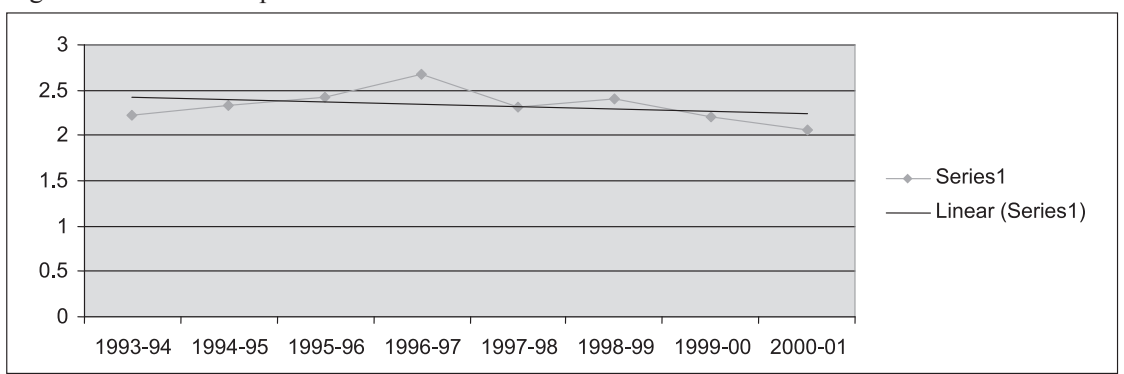

Source: Ministry of Finance, Economic Survey 2000-2001, p. 155

\begin{tabular}{lllll}
\hline JISR-MSSE & Volume 12 & Number 1 & January-June 2014 & 103
\end{tabular}


Figure 9. Expenditure on education as \% of GNP

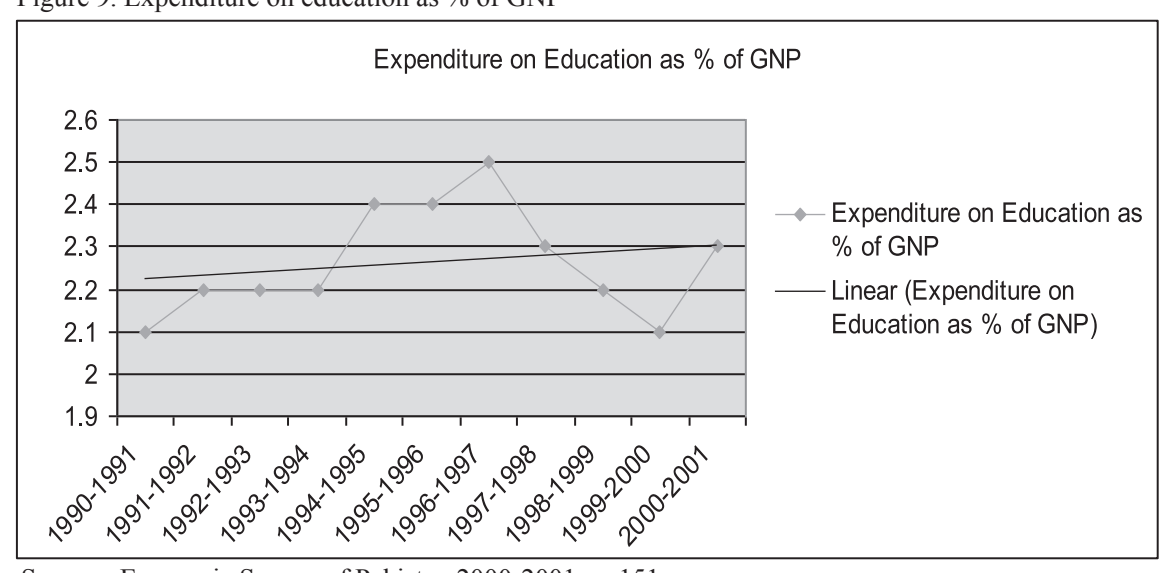

Source: Economic Survey of Pakistan 2000-2001, p. 151

There may be many other factors that could have contributed to this decline in education expenditure but our argument again refers to the SAP policies calling for balancing the budget which due to the nature of Pakistan's economy and political factors translates into cut in social sector expenditure and hence educational expenditure. After analyzing the impact of SAP on educational expenditure, following section will analyze the impact on education indicators.

\subsubsection{Impact of Structural Adjustment on Education Indicators}

Cut in educational expenditures has worst consequences for both the quality and quantity of education provided to students. Governments in the past have reacted by reducing education budget which has resulted in decline in real education expenditure per student. Hence cut in education expenditure affects both the quality and quantity of education provided to the population by any government and can be linked directly to structural adjustment programs. The impact of cut in expenditure on different education indicators has been analyzed. These include pupil to teacher ratio, enrolment ratio, availability of primary schools and availability of primary school teachers.

The pupil teacher ratio tells us about the number of students per teacher and hence is related to the quantity of education provided to students over the period of time. 
Figure 10. Pupil to teacher ratio

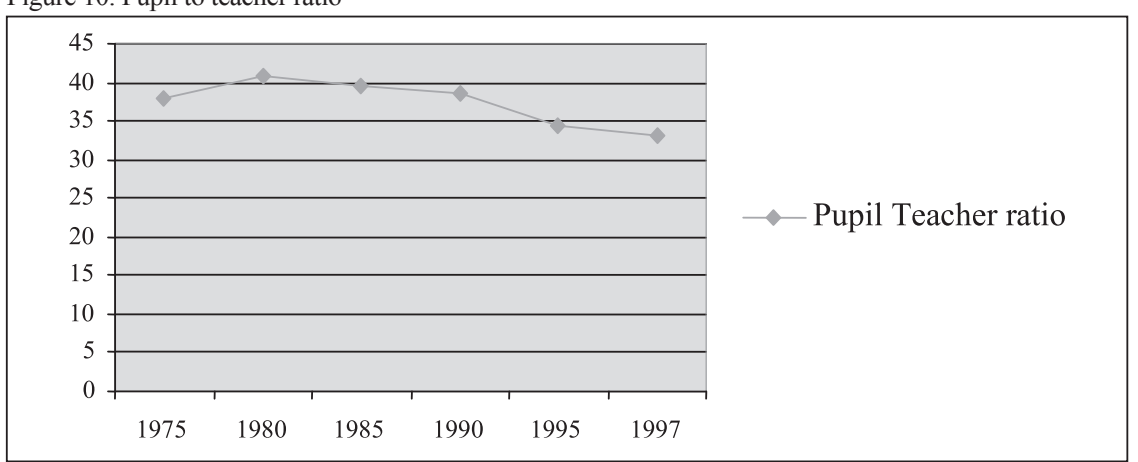

Source: Social Policy and Development Centre. Social Development in Pakistan: Annual Review 2000, Karachi.

Figure 10 analyses data from 1975 to 1997 and analyzes them on a chart. As the graph shows the ration increased from 1975 to 1980, then remained stagnant and later started declining till 1997 In other words, it means that the quantity of education has increased from 1985 till 1997 and it shows improvement over a period of time. This contradicts the UNICEF study (1987) arguments that education indicators get affected by SAP policies.

It also contradicts the conclusion of UNESCO Report (1995) which argues that structural adjustment led to decline in education expenditure and hence affected the education sector badly. The ratio declined sharply after 1994, onwards because of Social Action Program initiated by Benazir Bhutto government as it led to an increase in the government expenditure on social sector development. There can be other factors for the increase, for instance, increase in the pool of resources available to the government and Donor such as:

Figure 11. Availability of Primary Schools

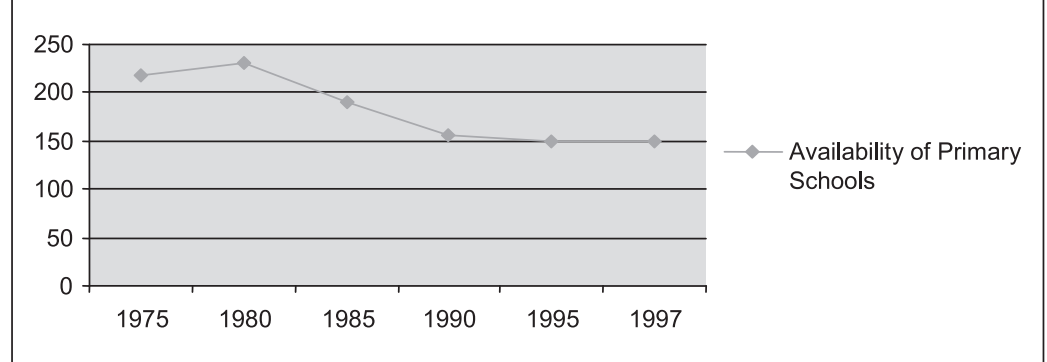

Source: Economic Survey of Pakistan 2000-2001

World Bank and Asian Development Bank support to the government. The availability of primary schools indicates the ratio of population to primary schools available. Lower the ratio, the better access to education. The graph shows the availability of Primary Schools ratio from 1975 to 1997. The ratio shows increase from 1975 to 1980, indicating a decline in access to education. The ratio becomes stagnant after 1990, i.e, during the adjustment era. This may mean that due to cut in government expenditure, construction of new primary schools declined or some schools became non functional due to lack of funds. 
Figure 12 analyzes the enrolment ratio of primary schools from 1975 onward. The ratio is stagnant during the initial period. It suggests poor performance of primary education. But there is an increasing trend in enrolment ratio from 1980 onwards and it shows a sharp increase from 1990 to 1995 . This means that the quality of primary education improved greatly from 1990 to 1995 . But after the year 1995, the enrolment ratio shows a declining trend hence meaning that the quality of education again declined during this period.

Figure 12. Enrolment Ratio

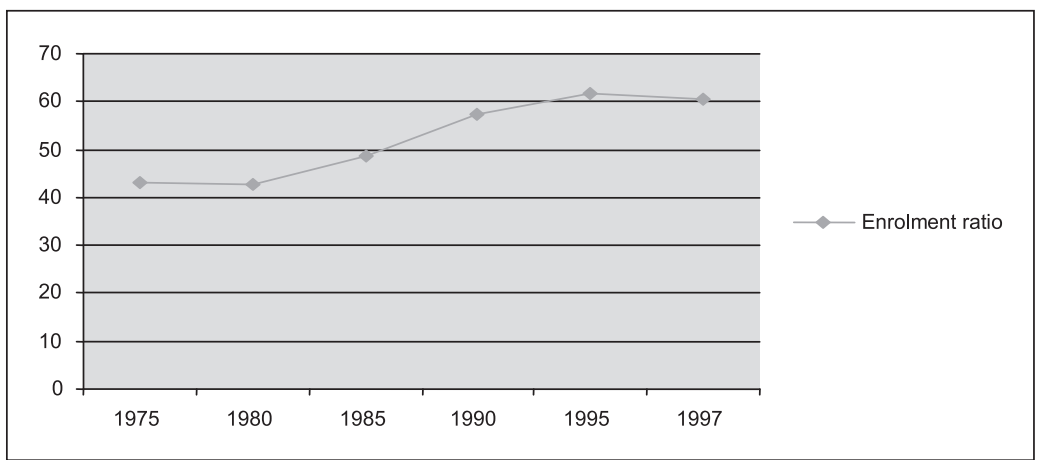

Source: Social Development in Pakistan: Annual Review 2000, Karachi.

The positive increase in 1995 can be attributed to the Social Action Program which allowed more funds for social sector and ensured improvement in development indicators during the period. A higher enrolment ratio means more students enrolment and hence better quality of education for the students.

Figure 13 analyzes the data regarding the availability of primary school teachers which informs about the ratio of primary students to the teachers. The greater the ratio the lesser will be the access to education for the students. A lower ratio would mean improvement in education indicators. This graph shows an increasing ratio till 1980, meaning lower quality of education, but then there is continuous decline in the ratio till 1995 . Hence, it can be conclude that the access to education improved during this period and proportionally more teachers were available for the population but after 1995, the graph becomes stable implying no improvement in education over the next few years. 


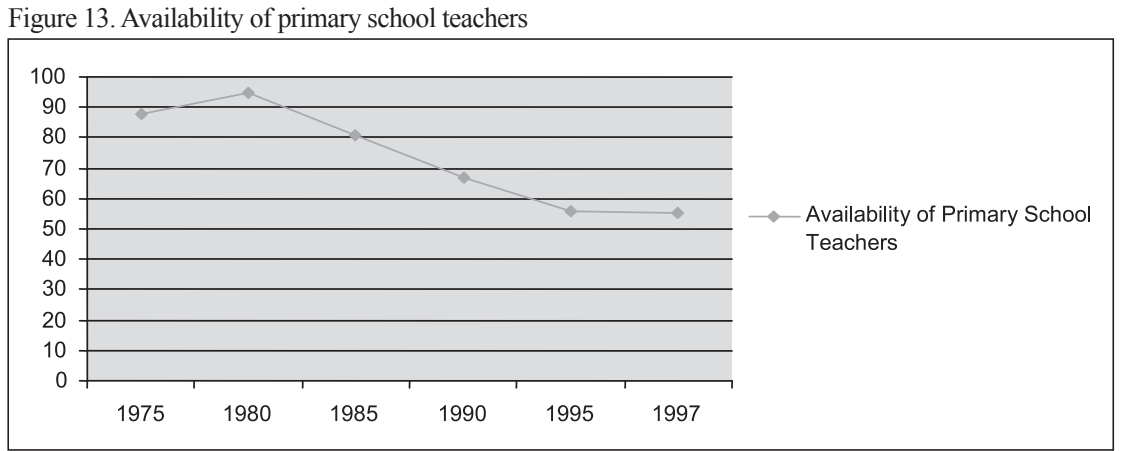

Source: Social Policy and Development Centre. Social Development in Pakistan: Annual Review 2000, Karachi.

The analysis of education indicators does not show any significant change due to adjustment policies. The results contradict the arguments of UNICEF study and UNESCO studies both of which suggest that Structural Adjustment led to decline in education indicators.

\subsection{Impact of Structural Adjustment on Unemployment in Pakistan}

The post Washington Consensus period was marked by strong hegemony of Neo liberal ideology and IMF was one of its major proponents. This ideology saw market as the most supreme entity and advocated broader socio-economic reforms to transform Third World economies from state-centric to market-centric economies. Hence, Structural Adjustment Programs advocated policy of market liberalization, privatization and deregulation. The economic downturn during 1990s prompted the Pakistan government to adopt Structural adjustment Program under IMF to reform the economy suffering from macroeconomic instability. A large numbers of Public sector institutions were sold out without realizing its negative impact on the socially marginalized working classes.

\section{Structural Adjustment Policies and Privatization}

Figure 14 analyzes the data on privatization of key industries from 1991 to 2006 to find out the impact of structural adjustment policies on Pakistan's economy. From 1991 to 2006 the GOP privatized more than 160 public units at gross price of Rs. 395 billion and about 0.6 million workers were rendered jobless as a result of neo-liberal IMF (SAP) policies. These results are consistent with the criticism of Stiglitz (2002) who in his work "Globalization and its discontents" argued that Privatization lead to negative impact on employment levels in the developing countries and leads to increased corruption in the process of privatization, thus affecting the marginalized social classes. 


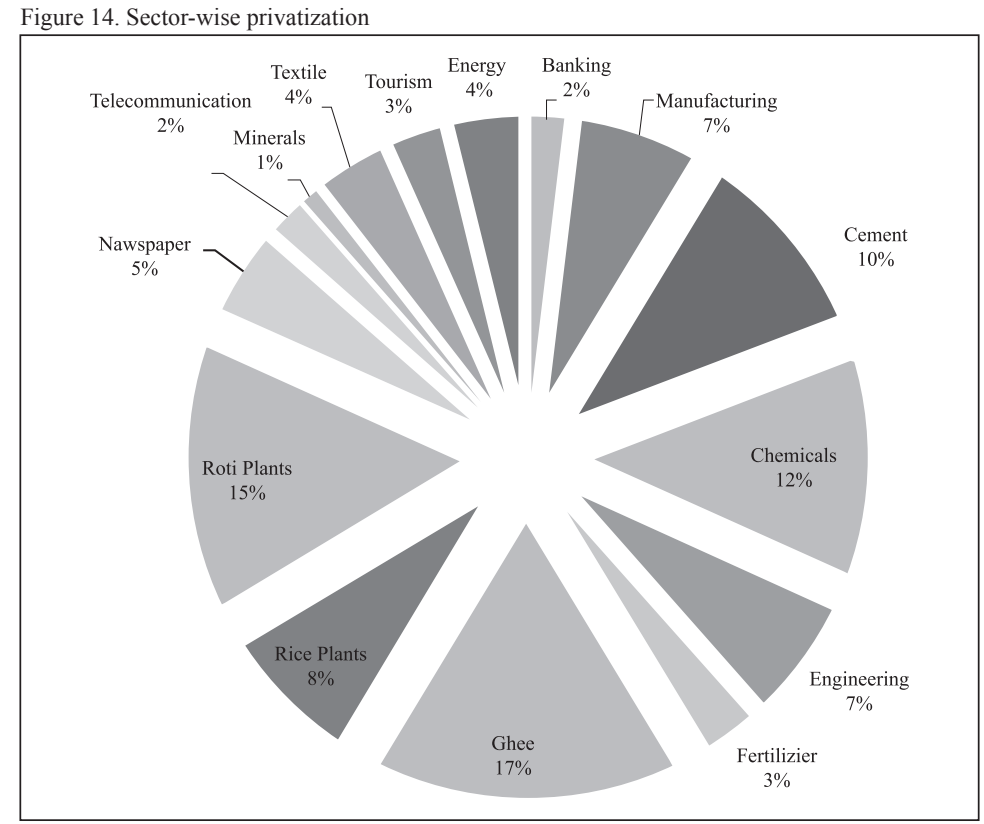

Source: Privatization Commission of Pakistan

Around 104 industries from different sectors of the economy were privatized and sold to corporations and individuals at different prices. The chart below shows the percentage of each sector in the number Privatized industries. The major sectors affected by privatization were Ghee (17\%), Roti plants (15\%), Chemicals (12\%), Cement $(10 \%)$, rice plants $(8 \%)$, manufacturing $(7 \%)$ and engineering $(7 \%)$. Ghee and Roti plants were most affected by the Privatization process.

\subsection{Impact on Unemployment}

After analyzing the impact of privatization on different industries, the impact of Privatization on unemployment in Pakistan will be analyzed. The graph shows the trend in unemployment rates from 1970-71 to 2000-01. The unemployment rate has increased steadily from $1970 \mathrm{o}$

Figure 15. Unemployment rate

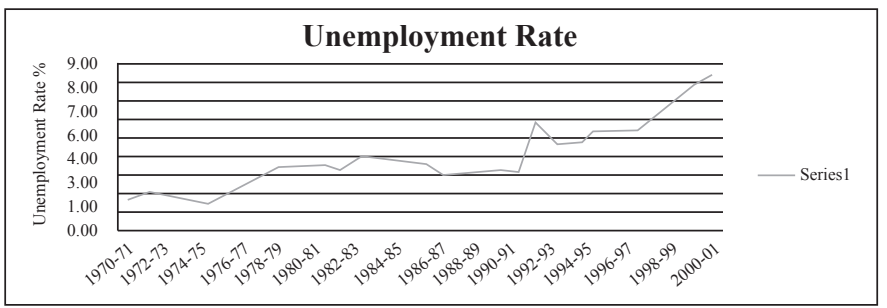

Source: Social Development in Pakistan: Annual Review 2000, Karachi 
Figure 16.

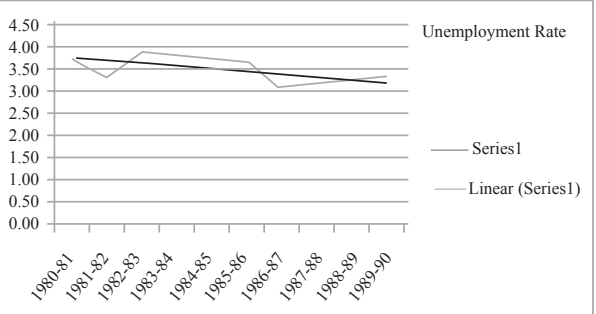

Source: Labor Force Survey: Various Years
Figure 17.

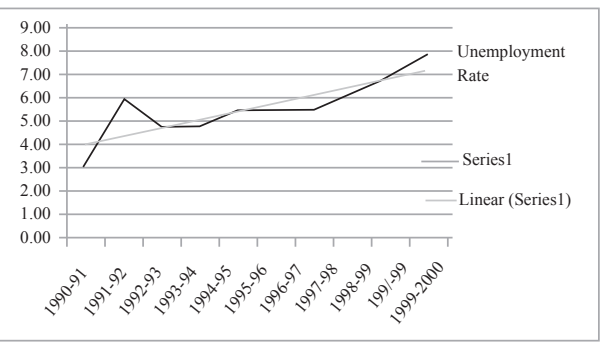

Comparing the unemployment data for two period's, i.e, pre-privatization and privatization periods, we can easily see that in the pre-privatization era, the unemployment rate shows a declining trend, whereas in the privatization period, unemployment rate shows an increasing trend. Hence, it can be concluded that privatization policy of SAP programs has led to increase in unemployment and badly affected the working class.

From the above discussion, it can be inferred that the IMF-led stabilization programmes in Pakistan have bitterly failed to bring about the desired results, if these are to be economic growth and some measure of progressive social development to deal with longstanding problems and inequities. Instead, they have produced further unemployment, inflation, poverty, economic dependency and political instability. Predictably, the IMF blames the enduring problems on the so-called 'crony capitalism' and the lack of political will on the part of politician to take bold decisions to implement conditionalities. While accepting that there is a great deal of institutionalized corruption within the system, this charge is rejected by independent observers. Rather, they argue that current conjuncture of global capitalist system itself is responsible for the spread of corruption and volatility in the country. Moreover, they argue that stabilization programmes systematically fail to take into account the socio-economic condition of the host country. They charge that IMF programmes lack a 'social matrix' and that is why they fail in the realization of their goals. Apart from that, their implementation negatively affects the poor and neglected sections of the society.

As noted above, the policy framework signed between IMF and Pakistan says something about protecting the poor from the effects of stabilization programmes by creating safety nets. But when it comes to details, hardly any measure is seen to be taken to protect the vulnerable classes from the brutish effects of stabilization programmes. Amartya Sen, quoted by UNDP Study (1996) has rightly said that SAPs in attempt to balance the budgets has unbalanced the lives of people (UNDP 1996). Given the nature and depth of Pakistan's integration into the international capitalist system and its dependency on aid from the IMF and World Bank and other international donors, it is hard for Pakistan to defy and de-link itself form global capitalist system. The political and policy options for change are very limited, yet attempt can be made to follow the policy of self-reliance.

\begin{tabular}{lll|l}
\hline JISR-MSSE & Volume 12 & Number 1 & January-June 2014 \\
\hline
\end{tabular}




\section{Criticism of IMF Programs}

The IMF Structural Adjustment Programmes have been criticized by the civil society as these programmes had adversely affected the marginalized and vulnerable section of the society most. According to UNDP Report (1996), the design of the SAP almost misses the element of human factor and assigns very least importance to it. The report notes, "During the whole process of liberalization, adjustment and privatization, concern for the poor was pushed into the background. The policy makers assumed that even if poverty increased in the short term, this was a price that had to be paid for long term stability" In other words, the poor, especially women and children were used by the IMF and World Bank as "Human Buffer" for the enrichment and protection of the interests of the rich classes.

From the record, it is abundantly clear that the conditions attached with the IMF package of 1988 were the most severe in the history of IMF-Pakistan relations. There was uproar in the media and civil society against the harshness of the IMF conditionality's. Writing about the IMF programme, one analyst wrote:

The IMF package is regarded even in Fund and World Bank circles as a tough one and excessively harsh which has multiplicity of social implication leading to Venezuelan situation which led to 300 deaths to price riots (Tarik Saadat, 1989).

In view of the inappropriateness of the conditionality's and the fact that the new government at that time accepted all the terms and conditions agreed by the previous caretaker government regime, questions were raised regarding the future stability of the government. According to one of a society activist Anjum Ibrahim:

The crucial question is: Why did Ms Bhutto accept all the conditionality's imposed by the IMF. It is true that she had as little choice as that available to Mr Branko Mikulic; yet one feels that Ms Bhutto is relying heavily on support from the public. She must realize that nobody is going to continue to support to her if people do not know where the next meal is coming from" (Business Recorder, 1989).

It is true that the IMF is insensitive to the criticism (Stiglitz, 2002). There were severe kinds of criticism in media against the anti-poor nature of the IMF structural adjustment programmes and it demanded the renegotiation of stringent terms and conditions. So, instead of listening to the saner voices from the civil society, IMF issued stern warning and its official made it clear that:

Pakistan may lose its entitlement of Structural Adjustment Facility (SAF) if it calls for renegotiation". ....the quantum will be bigger but the conditionality's will be much tougher" (The Muslim, 1988).

While commenting on the IMF programmes and pleading for the policy of self-reliance, a Lahore-based NGO opined against fund's policies in the following words:

Ever since Pakistan began borrowing money from the US-dominated World Bank and IMF, our economic woes have multiplied ......To break IMF shackles we shall have to learn to live within our own resources...... and above all stop borrowing from IMF-World, the US dominated 'donor agencies" (Business Recorder, 2001). 
Most political and economic analysts have been saying all along that the IMF plays as the role of tool to promote the strategic interests of US. According to Dawn, the proposed IMF facility was:

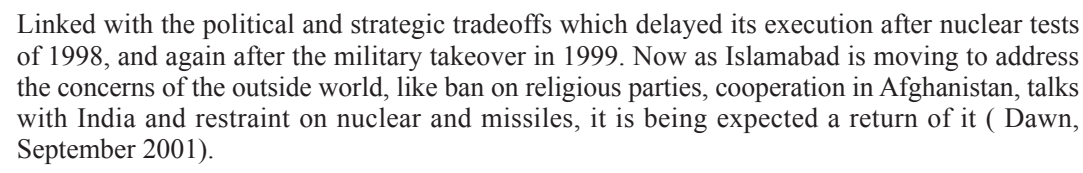

The above-mentioned observations show the negative and poor perception developed on the part of the IMF regarding prospects of funding for Pakistan. Though, the economic variables affecting the IMF preconditions and performance criteria remained same, the post 9/11 IMF changed its policy drastically towards Pakistan. Before taking any decision on 'bail-outpackage' and PRGF, the IMF waited for Pakistan's response to the international coalition's call for cooperation in fight against terrorism:

$$
\begin{aligned}
& \text { Pakistan's relationship with financial markets is largely dependent on its ability to appease the } \\
& \text { United States regarding the enraged superpower's intended action against Osama bin Laden and } \\
& \text { Afghanistan in retaliation for the Tuesday's carnage. All multilateral lenders and other related } \\
& \text { institutions are looking out as to what stance Islamabad's military takes" (The Nation, 2001). }
\end{aligned}
$$

The fund's reaction to the politically changed situation is evident from the fact that immediately after Pakistan's decision to go along with the US-led international coalition against terrorism, the IMF indicated softening of its position on the concessional PRGF by stating:

The United States being one of the key stakeholders in international financial institutions IMF and the World Bank, is expected to be much more favorable than in the past.......Pakistan's recent pledge to work with the international community against terrorism is expected to win a lot of support from the financial institutions" (Dawn, 2001).

When the military regime of Musharraf expressed its willingness to join the 'coalition of the willing', the chief of IMF Horst Kohler appreciated the performance of Pakistan economy in the following words:

Pakistan has recently begun performing better under the existing standby arrangement making it likely that discussion about a new antipoverty loan would prove fruitful. We have reviewed the situation and agreed with the United States that we need to closely monitor the situation and discuss what could be done if thing could get worse" (Nation, 2001).

The political aspect of the PRGF was also highlighted by the well reputed newspaper New York Time's portraying PRGF more in the political light than in economic. According to the newspaper:

The Bush administration was found overlooking the lapses that may have slowed the release of IMF loan earlier. The United States is the Fund's single largest shareholder, with Europe and Japan close behind, so the Fund tends to make loans to support their top diplomatic priorities" (The News, 2001). 
It is evident from the above discussion that there was a sudden and positive change of perception and behavior on the part of the IMF after the changed political environment arising out of US-Pakistan convergence of interests in war against terrorism. The Fund's prompt action for the release of last tranche to the tune of $\$ 1.7$ under standby agreement of 2000, and commitment for provision of Poverty Reduction and Growth Facility was 'expedient, episodic and out of routine'. Neither the principles of economic liberalism, nor the qualitative dimensions of the concept of multilateralism were observed in policy output of the multilateral body. The rationalization of IMF outputs on political grounds raises the issue of linkage between US bilateral political realism and multilateral financial institution economic liberalism. It really goes against the very charter of IMF and basic principle of Keynesianism, and Keynes must have been tossing over in his grave to see how his brainchild is being misused to protect the interests of big business instead of people who at the end of the day emerged to be the major victims of IMF's conditionalities-ridden programmes.

\section{Conclusion}

Apparently, Pakistan singed different structural adjustment agreement with IMF to improve its economy and create stable economic environment for sustainable economic environment but it did not happened for variety of reasons. According to Dr. Ishrat Hussain (2001) Pakistan joined IMF for political reason than economic ones. It joined IMF for mere getting access to private credit which it could not get without signing agreement with IMF. So, according to Dr. Ishrat (2001), there were political reason for the failure of IMF programmes as different elected government were not willing to implement IMF conditionalities due to inflationary nature of the programmes. Further, some of the agreements with IMF were singed by interim governments such as government of Moin Haider, who was working with World Bank before his appointment as caretaker prime minster. So, there was the question of ownership of agreement and elected government of Nawaz Shairf and Benazir Bhutto showed reluctance to own and implement conditionalities as they were not signatories to some of the agreements. But both the leaders were under tremendous pressure to implement IMF conditionalities. Interestingly none of the regime implemented fully the IMF conditions and as a result loans had to be suspended after the payment of couple of tranches. It was for this reason; Pakistan was dubbed as 'one tranche' country.

The other reason for the failure of the IMF programmes was that they focused too much on financial stability and ignored long-term developmental goals, industrialization, higher employment or increased public investment. Moreover, according to critics, the main reason of the failure of IMF programmes is that it ignores the social matrix in which it operates and imposes conditions that affect the poor. For the sake of macroeconomic stability, it ignores the microeconomic stability. Its conditionality such as austerity under which the subsidy is withdrawn on the social sector often hurts the people at bottom of the pyramid. This, too, was seen in Pakistan during nineties when the health and education were severely affected as result of government's efforts to fix the fiscal problems. It had to cut health and education budget. The privatization also produced negative social consequence and thousands of the people lost their jobs. It created social tensions and political instability due to which nine governments were changed in the span of 11 years. 
To sum up, the IMF programmes produced devastating social consequences for poor and middle classes of Pakistani society. And for this the inflationary nature of programmes, designed to control and curb demand, is blamed. Further, keeping in view the inflationary nature of the programmes, government would have set up social safety nets to protect poor from the harmful effects of the conditionalities but ironically no step was taken in this regard. As such people faced social repression due to IMF programmes during the decade of nineties.

\section{References}

Beke, A. O. D. (2002). MF Activities to Promote Good Governance and Combat Corruption: An Overview, IMF, Policy Development and Review Department. Retried from http://info.worldbank.org/etools/docs/library/207469/assessing/pdf/op_de_becke.pdf

Cornia, A. G., Richard, J., \& Frances, S. (1987). Adjustment with a Human Face, Protecting the Vulnerable and Promoting Growth, A Study by UNICEF. New York: OUP.

Engdahl, W. F. (2009). Are Ukraine Black Death Cases Result of IMF Loans?, Retrieved from http://www.oilgeopolitics.net/Swine_Flu/Ukraine_Deaths/ukraine_deaths.html

Gera, N. (2007). Structural Adjustment Programes in Pakistan: A Boon or Bane, Lahore School of Economics. Retrieve from www.econbizde/record/impact--of...on...geranina/ 10003502353.

Government of Pakistan, 2002, Social Development in Pakistan, Annual Review, pp.522-526 Social Policy and Development Centre, Karachi.

Hameed \& Nazeer (2013). Economic Globalization and its Impact on Poverty and Inequality, Retrieve from

http://www.ecosecretariat.org/ftproot/Publications/Journal/1/Article_TDB.pdf

Hussain, I. (2001, August 28). Debt, Deficit and Dollars, Dawn.

Husain, I. (2004). Economic Reforms and Macroeconomic Management in Pakistan (19992001). Karachi: Oxford University Press.

Kemal, A. R. ( 2001). Structural Adjustment, 2001.Macroeconomic Policies and Poverty Trends in Pakistan. Proceedings of Asia and Pacific Forum on Poverty: Reforms Policies and Institutions for Poverty reduction, Asian Development Bank, Manila, 59 February, 2001.

Khan, M. S., Peter, M. \& Haque, N. U. (1990). Adjustment with Growth, Relating the Analytical Approaches of the IMF and the World Bank, Journal of Development Economics, 32 (1), 155-179. 
Khan, M. A. (2002). Review of Social Sector and Social Action Programme, Pakistan Human Condition Report (2002). Government of Pakistan, Centre for Research on Poverty Reduction and Income Distribution, Islamabad.

Khan. S. R. (1999). Do World Bank and IMF Policies Work? Basingstoke: Macmillan Press Ltd.

Rogoff, K. (2003). The IMF Strikes Back, Foreign Policy Magazine, Retrived from http://scholar.harvard.edu/rogoff/publications/imf-strikes-back

Rowden, R. (2009). The deadly ideas of neoliberalism: How the IMF has undermined public health and the fight against AIDS. London: Zed Books.

State Bank of Pakistan (2005). Statistics of Pakistan Economy, A Handbook, pp.151-152.

Stiglitz, J. (2002). Globalization and its Discontents. London: Penguin Books.

Tarik, S. (1989, May 20). The way out of logjam of conditionalities. The Nation.

Transparency International (2013). Corruption Perceptions Index.

Retrieved from http://www.transparency.org/cpi2013/results

UNDP (1996). Human Development Report. Retrieved from http://hdr.undp/sites/default/files/reports/257/hdr_996.

UNESCO Report (1995). EFfects Of Structural Adjustment On Education And Training, UNESCO. Retrieved from http://unesdoc.unesco.org/images/0010/001013/101342e.pdf

Veerland, J. R. (2007). The International Monetary Fund: Politics of Conditional Lending, New York: Routledge.

Zaidi, A. (2006). Issues in Pakistan Economy, Karachi: Oxford University Press. 